\title{
Experimental Study on Lightning Attachment Manner to Rotation Wind Turbine Blade
}

\author{
Zixin Guo \\ State Key Lab of Alternate Electrical \\ Power System with Renewable Energy \\ Sources \\ North China Electric Power University \\ Beijing, China \\ guozixin@ncepu.edu.cn \\ Waqas Arif \\ State Key Lab of Alternate Electrical \\ Power System with Renewable Energy \\ Sources \\ North China Electric Power University \\ Beijing, China \\ waqasarif@qq.com
}

\author{
Qingmin $\mathrm{Li}$ \\ State Key Lab of Alternate Electrical \\ Power System with Renewable Energy \\ Sources \\ North China Electric Power University \\ Beijing, China \\ lqmeee@ncepu.edu.cn \\ Yufei Ma \\ State Key Lab of Alternate Electrical \\ Power System with Renewable Energy \\ Sources \\ North China Electric Power University \\ Beijing, China \\ 15652912154@163.com
}

\author{
Wanshui $\mathrm{Yu}$ \\ State Key Lab of Alternate Electrical \\ Power System with Renewable Energy \\ Sources \\ North China Electric Power University \\ Beijing, China \\ yu_wanshui@qq.com \\ Wah Hoon Siew \\ Department of Electronic \& Electrical \\ Engineering \\ University of Strathclyde \\ Glasgow, United Kingdom \\ wh.siew@strath.ac.uk
}

\begin{abstract}
Lightning strike is one of the most serious damages to the wind turbine blade. The blade is in rotation when lightning strike happens. The influence of the rotation to the lightning attachment manner of wind turbine blade is not fully studied. Experimental work has been done in this paper. A 1:30 scale 3MW wind turbine is built. There are 3 side receptors on each blade according to the real wind turbine blade. A rod electrode is used as the high voltage electrode to simulate the downward leader. Both negative and positive $250 / 25000 \mu$ standard switching impulses are applied. Different blade tip linear speeds, equal to the real wind turbine, are used to study the influence of the blade rotation to attachment process. The results show that the influence of the rotation can be classified into two types, one is the impact on the location of the striking attachment point, the other is the impact on the discharge channel close to the blade. The influence depends on the polarity of the discharge. Positive discharge is more dangerous to wind turbine blade in rotation.
\end{abstract}

Keywords-lightning protection, wind turbine blade, rotation, receptor, lightning attachment

\section{INTRODUCTION}

Wind power generation has become one of the most important renewable energies of the world. In China, over 100000 wind turbines have been installed at the end of 2017 . With the increasing of the onshore and offshore wind turbine, more and more lightning accidents have been reported. The damage rate of wind turbine blade in China is about $1 \%$ and for some thunderstorm area it can reach $5 \%$, according to the data of Chinese Wind Energy Equipment Association.

Most of wind turbines are equipped with lightning protection system (LPS) [1]. However, the existing LPS doesn't provide enough protection to the blades. Many experimental researches have been done with real wind

This project is supported by National Natural Science Foundation of China (51420105011) and Fundamental Research Funds for the Central Universities (2016XS06). turbine blade tip specimen to improve the design of the LPS [2]-[7]. The blade is in rotation when lightning accident happens. Field observation indicates that the wind turbines in rotation are more likely to be hit by lightning strikes [8]-[10]. The breakdown voltages of static and rotation blade have been compared by using a scale wind turbine with an arching electrode [11]. The attachment process of the rotation wind turbine blade remains to study.

In this paper, a scale rotation wind turbine is built, and the same linear speed of the real wind turbine is used. Both negative and positive standard switching impulses are applied. The influence of the rotation to attachment process under different polarity impulse has been studied.

\section{EXPERIMENT WORK}

\section{A. Scale wind turbine model}

A 1:30 scale rotation wind turbine model is built, according to a real $3 \mathrm{MW}$ wind turbine (Fig. 1). The height of the steel tower is $4 \mathrm{~m}$. The length of the blade is $1.8 \mathrm{~m}$. The blade is made of glass fiber reinforced polymer (GFRP). There are three aluminum side receptors (named \#1, \#2, and \#3 from the blade tip) on the blade. The location of the receptors is shown in Fig. 2. The radius of the receptor is $0.5 \mathrm{~cm}$. The receptors are connected by $10 \mathrm{~mm}^{2}$ copper down conductor. A commutator is used in the hub to connect the down conductor in the blade and the tower. The hub is connected to the motor with the same shaft and the motor is installed in the nacelle. The nacelle is protected by grounded steel mesh outside. The motor is powered by a small generator to eliminate the influence of the change of the ground potential due to the discharge. 

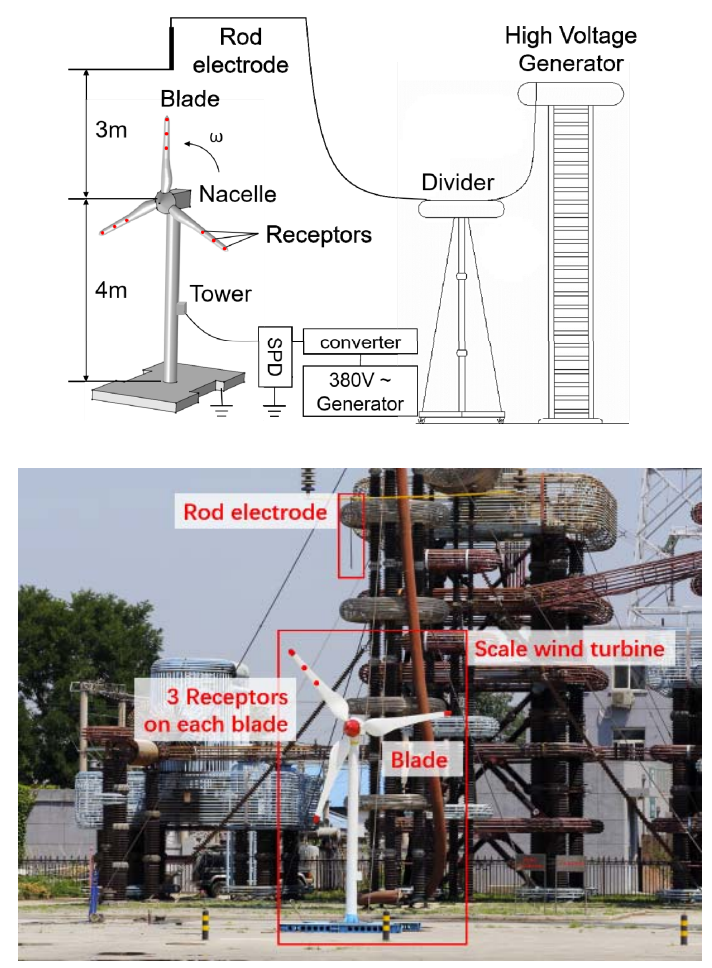

Fig. 1 The 1:30 scale rotation wind turbine model

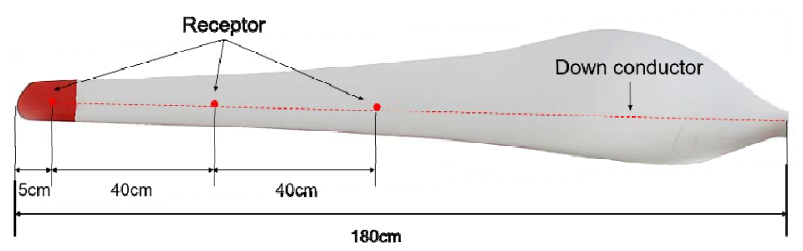

Fig. 2 The arrangement of the receptors

\section{B. Experimental setup}

A rod electrode is used as the high voltage electrode to simulate the downward leader. The distance between the rod electrode and the nacelle is $3 \mathrm{~m}$. the electrode is right above the scale wind turbine.

The electric field produced by switching impulse is more similar with that of real lightning strikes [12]. The $250 / 2500 \mu$ s standard switching impulse is used as the testing waveform. Although about $90 \%$ natural lightning strikes are negative, the positive ones are more destructive. So, both negative and positive impulses are use in the experiments.

The length of a 2 - 3MW wind turbine blade is about $50 \mathrm{~m}$, and the rotational speed is about $6-20 \mathrm{r} / \mathrm{min}$. The linear speed of the blade tip can range from $40-100 \mathrm{~m} / \mathrm{s}$. Some parameters of 2 - 3MW wind turbines are shown in Table I. To simulate the linear speed of the real wind turbine blade tip, $0 \mathrm{r} / \mathrm{min}, 200 \mathrm{r} / \mathrm{min}$ and $350 \mathrm{r} / \mathrm{min}$ are used as the speed of the scale wind turbine, which the linear speeds are $0 \mathrm{~m} / \mathrm{s}$, $37.68 \mathrm{~m} / \mathrm{s}$ and $65.94 \mathrm{~m} / \mathrm{s}$, respectively.
TABLE I PARAMETERS OF 4 TYPES OF 2-3MW WIND TURBINES

\begin{tabular}{ccccc}
\hline Model & $\begin{array}{c}\text { Capacity } \\
\text { (MW) }\end{array}$ & $\begin{array}{c}\text { Length } \\
\text { of } \\
\text { blade } \\
\text { (m) }\end{array}$ & $\begin{array}{c}\text { Range of } \\
\text { rotational } \\
\text { speed } \\
(\mathbf{r} / \mathbf{m i n})\end{array}$ & $\begin{array}{c}\text { Linear } \\
\text { speed of } \\
\text { the blade } \\
\text { tip (m/s) }\end{array}$ \\
\hline Vestas V90 & 2 & 44 & $8.6-18.4$ & $39.6-84.7$ \\
Vestas V112 & 3 & 54 & $6.7-17.7$ & $37.9-100.0$ \\
$\begin{array}{c}\text { Sinovel } \\
\text { SL3000/105 }\end{array}$ & 3 & 50 & $7.5-17.5$ & $39.5-92.1$ \\
Goldwind & 2 & 56.5 & $14.5-18.2$ & $85.7-107.6$ \\
GW115 & 2 & & & \\
\hline
\end{tabular}

Both static and rotational experiments are conducted under both negative and positive standard switching impulses. For the static condition, experiments are conducted under four different blade orientations, which are $30^{\circ}, 45^{\circ}$, $60^{\circ}$, and $90^{\circ}$ with horizontal, as shown in Fig. 3. For the rotational condition, two different speeds (200r/min, $350 \mathrm{r} / \mathrm{min}$ ) are used. The impulse is generated by $5400 \mathrm{kV}$ impulse voltage generator in NCEPRI. A digital camera and a high-speed camera are used to record the attachment process. The speed of the high-speed camera is $240616 \mathrm{fps}$.

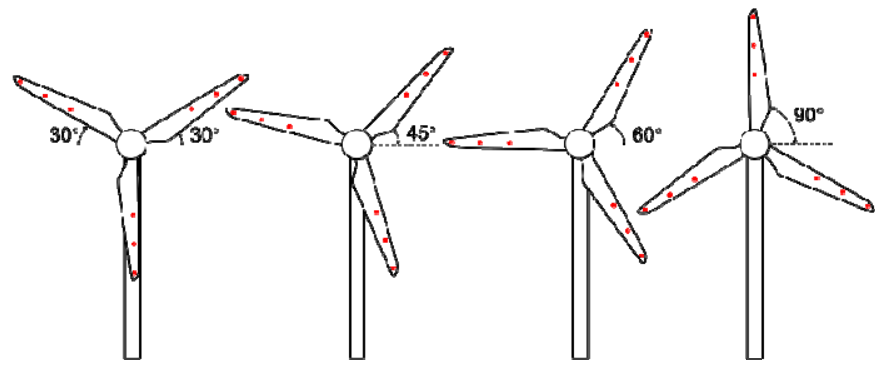

Fig. 3 Four types of wind turbine blade orientations

\section{EXPERIMENT RESULTS}

\section{A. Attachment manner under negative switching impulses}

Table II and Fig. 4 shows the results of negative experiments. The side receptor works well and intercepts all the discharges. All the striking attachment points are located at \#1 receptor for both static and rotation condition. There are no observably difference on the location of striking attachment point between the static and rotation results.

TABLE II RESULTS OF THE ATTACHMENT MANNER OF WIND TURBINE BLADE UNDER NEGATIVE STANDARD SWITCHING IMPULSE

\begin{tabular}{|c|c|c|c|c|c|}
\hline \multirow{2}{*}{$\begin{array}{c}\text { Rotational } \\
\text { speed } \\
\text { (r/min) }\end{array}$} & \multirow[b]{2}{*}{$\begin{array}{c}\text { Blade } \\
\text { orientation }\end{array}$} & \multirow{2}{*}{$\begin{array}{c}\text { Breakdown } \\
\text { voltage }^{a} \\
(\mathbf{k V})\end{array}$} & \multicolumn{3}{|c|}{ Striking attachment point } \\
\hline & & & $\begin{array}{c}\# 1 \\
\text { Rece- } \\
\text { ptor }\end{array}$ & $\begin{array}{c}\# 2 \\
\text { Rece- } \\
\text { ptor } \\
\end{array}$ & $\begin{array}{c}\# 3 \\
\text { Rece- } \\
\text { ptor } \\
\end{array}$ \\
\hline Static & $90^{\circ}$ & -1020.43 & 20 & - & - \\
\hline Static & $60^{\circ}$ & -1284.92 & 20 & - & - \\
\hline Static & $30^{\circ}$ & -1731.49 & 20 & - & - \\
\hline 200 & - & - & 20 & - & - \\
\hline 350 & - & - & 20 & - & - \\
\hline
\end{tabular}

a. The breakdown voltage is the average instantaneous value of all the discharges under the same condition. 


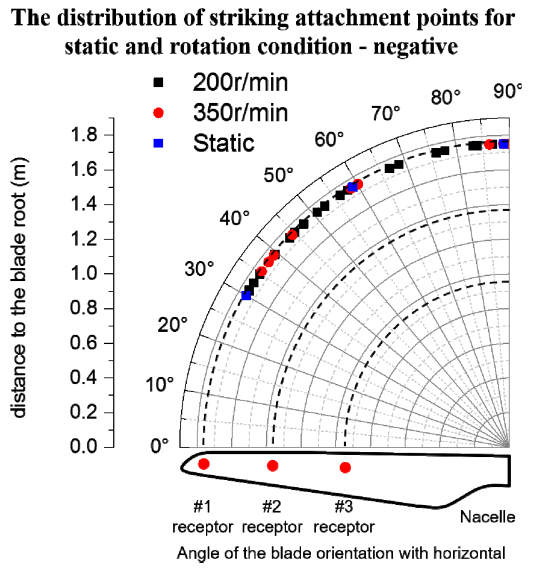

Fig. 4 The distribution of the striking attachment points for static and rotation condition (negative)

For static condition, no damages are made on the receptor or on the blade surface near the receptor. Upward leaders are observed being incepted from the \#1 receptor under all the three blade orientations, as shown in Fig. 5. It is worth being noted that, the upward leader can be divided into two patterns from the static results, $1 / 3$ of the upward leaders develop in the air near the blade (Fig. 6(a)), and the other $2 / 3$ of the upward leaders develop along the blade surface (Fig. $6(b))$.
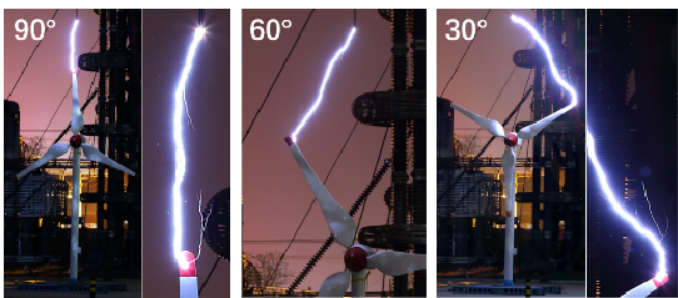

Fig. 5
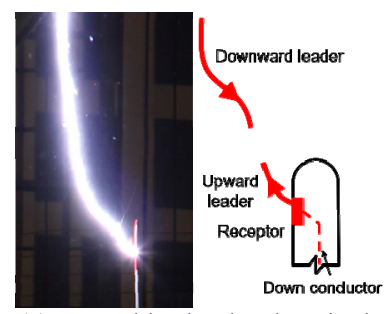

(a) upward leader develops in the air near the blade

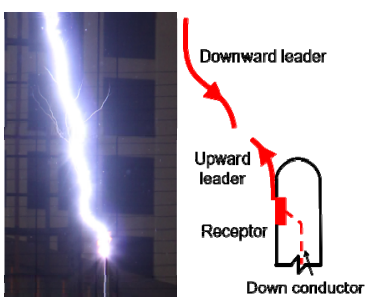

(b) upward leader develops along the blade surface
Fig. 6 The path of upward leader incepting from the receptor

There are some puncture damages near the receptor reported from the field observation, and the junction of the beam and the core material is the most vulnerable position of the blade from experimental study [13]. So, although the receptor intercepts the downward leader successfully, it may still cause damages due to the path of the discharge near the receptor. There are two suggestions proposed by this paper to improve the performance of the wind turbine blade LPS against lightning strikes, one is that reinforcing the strength of the material near the receptor to withstand the discharge, the other is that modifying the design of the receptor to avoid upward leader developing along the blade surface.

For rotation condition, the path of the discharge near the receptor is in arc-shape, as shown in Fig. 7. The length of the arc-shape channel ranges from $0.2 \mathrm{~m}(200 \mathrm{r} / \mathrm{min})$ to $0.3 \mathrm{~m}$ (350r/min). Surface scorching may happen on the blade surface near the receptor (Fig. 8), which is reported by real wind turbines [14]. The length of the scorching mark ranges from $21.2 \mathrm{~mm}(200 \mathrm{r} / \mathrm{min})$ to $32.6 \mathrm{~mm}(350 \mathrm{r} / \mathrm{min})$. The blade orientation is random when the discharge happens, however, all the marks caused by surface scorching are in the opposite direction of the rotation.

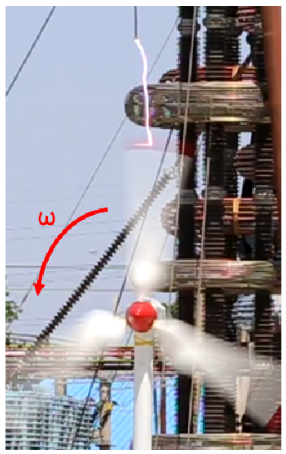

(a) Scale wind turbine

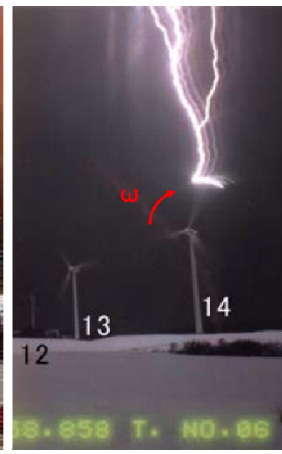

(b) Field observation
Fig. 7 The arc-shape discharge channel near the receptor

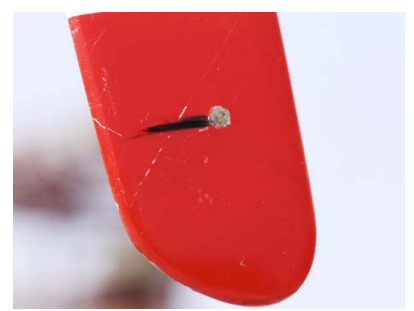

Fig. 8 Surface scorching phenomenon

\section{B. Attachment manner under positive switching impulses}

Table III and Fig. 9 shows the results of positive experiments. The location of the striking attachment points is significantly different from that of negative experiments.

\begin{tabular}{|c|c|c|c|c|c|c|c|c|}
\hline \multirow{2}{*}{$\begin{array}{c}\text { Rotational } \\
\text { speed } \\
(\mathbf{r} / \mathrm{min})\end{array}$} & \multirow{2}{*}{$\begin{array}{c}\text { Blade } \\
\text { orientation }\end{array}$} & \multirow{2}{*}{$\begin{array}{c}\text { Breakdown } \\
\text { voltage }^{\text {a }} \\
(\mathbf{k V})\end{array}$} & \multicolumn{5}{|c|}{ Striking attachment point } & \multirow[b]{2}{*}{ total } \\
\hline & & & $\begin{array}{c}\# 1 \\
\text { Receptor }\end{array}$ & $\begin{array}{c}\# 2 \\
\text { Receptor }\end{array}$ & $\begin{array}{c}\# 3 \\
\text { Receptor }\end{array}$ & $\begin{array}{l}\text { Blade } \\
\text { body }\end{array}$ & Nacelle & \\
\hline Static & $90^{\circ}$ & 641.01 & 20 & - & - & - & - & 20 \\
\hline Static & $60^{\circ}$ & 881.66 & 20 & - & - & & - & 20 \\
\hline Static & $45^{\circ}$ & 1073.13 & 11 & 9 & - & - & - & 20 \\
\hline Static & $30^{\circ}$ & 1103.57 & - & 10 & 10 & - & - & 20 \\
\hline 200 & - & - & 15 & 3 & - & 1 & 1 & 20 \\
\hline
\end{tabular}

a. The breakdown voltage is the average instantaneous value of all the discharges under the same condition. 
Where the discharge hits on the blade depends on the orientation of the blade whenever the blade is static or in rotation.

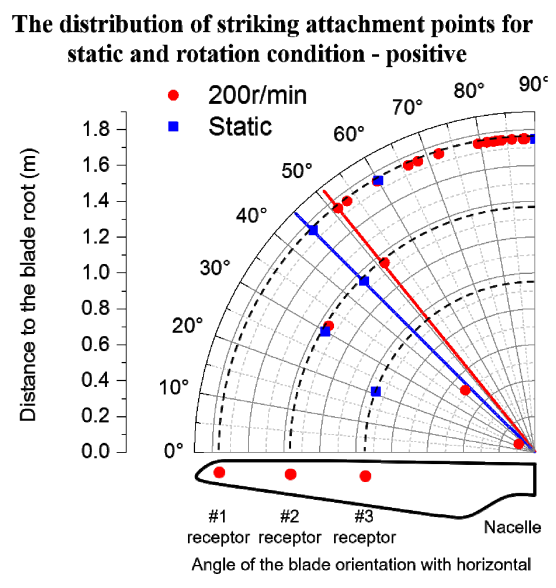

Fig. 9 The distribution of the striking attachment points for static and rotation condition (positive)

For static condition, all the downward leaders are intercepted by receptors. However, the receptors that attract the downward leaders are significantly different with that of negative discharges. When the blade orientation is larger than $45^{\circ}$ with horizontal, the $\# 2$ or $\# 3$ receptor will intercept the downward leader instead of the \#1 receptor, as shown in Fig. 10. Multiple upward leaders can be observed incepting from \#2 and \#3 receptors of different blades, as shown in Fig. 11. There is even no corona or upward leader incept from the \#1 receptor. It is indicated that the receptors far from the blade tip are necessary for LPS of wind turbine blade against positive lightning strikes.

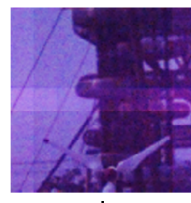

$t=0$ Hs

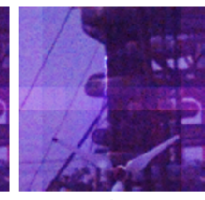

$t=4.156 \mu s$

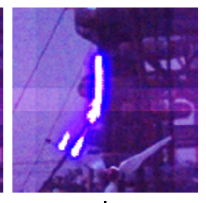

$\mathrm{t}=8.312 \mu \mathrm{s}$

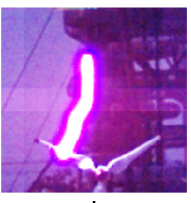

$t=12.468 \mu s$ $t(\mu s)$

Fig. 10 The \#2 and \#3 receptor intercept the downward leader instead the \#1 receptor for positive discharge under blade orientation larger than $45^{\circ}$

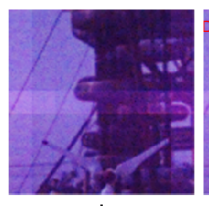

$t=0 \mu s$

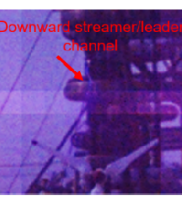

$t=4.156 \mu s$

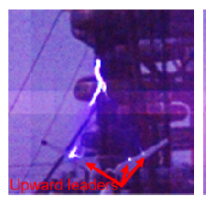

$t=8.312 \mu s$

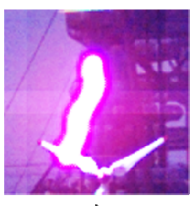

$t=12.468 \mu \mathrm{s}$
Fig. 11 Multiple upward leaders incept from different receptors of different blades

For rotation condition, some positive discharges hit on the blade surface and the nacelle rather than the receptors. As shown in Fig. 12, the discharges may hit on the blade surface and the nacelle when the blade orientation is near $30^{\circ}$ with horizontal in rotation. The critical angle of the blade orientation that the \#1 receptor fails to intercept downward leader in rotation condition is about $50^{\circ}$, which is larger than that of static condition $\left(45^{\circ}\right)$ (Fig. 9). Both the critical angle and the case that all the receptors fail to attract downward leader indicate that the rotation blade is more vulnerable to be hit by positive lightning strikes. However, there is no significantly difference for negative discharges between static and rotation condition. It is worth being noted that there is no obvious arc-shape channel for positive discharges. The reason may be that the linear speed of the \#2 or \#3 receptor is small than that of the \#1 receptor.

One of the reasons why the \#1 receptor fails to attract downward leader is that it difficult for negative upward leader to incept it. Table IV shows the length of the downward leader when upward leader incepts under negative and positive discharges. Negative upward leader incepts much later than the positive one, so there is not enough time for \#1 receptor to attract the downward leader and the downward leader finds a closest point to hit on.

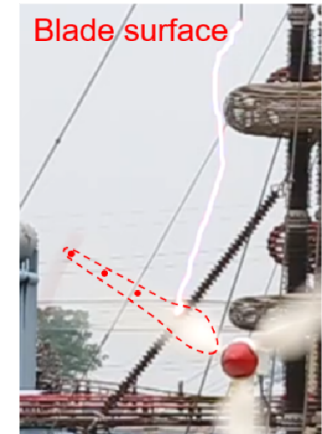

(a)

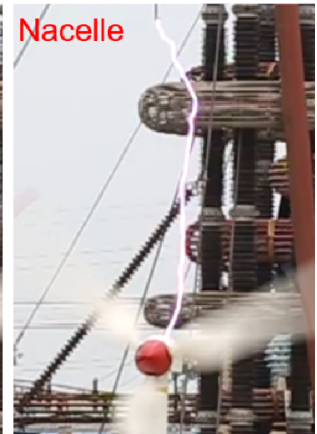

(b)
Fig. 12 Positive discharges hit on (a) the blade body and on (b) the nacelle

\begin{tabular}{cccc} 
TABLE IV & $\begin{array}{c}\text { THE LENGTH OF THE DOWNWARD LEADER WHEN THE } \\
\text { UPWARD LEADER INCEPTS }\end{array}$ & \\
\hline Polarity & $\begin{array}{c}\text { Rotation } \\
\text { speed } \\
\text { (r/min) }\end{array}$ & $\begin{array}{c}\text { Ratio between the } \\
\text { length of the downward } \\
\text { leader and the whole air } \\
\text { gap }\end{array}$ & SD \\
\hline Negative & 200 & $20.77 \%$ & 0.1085 \\
Negative & 350 & $13.59 \%$ & 0.0674 \\
Positive & 200 & $44.14 \%$ & 0.1008 \\
\hline
\end{tabular}

\section{DISCUSSION}

The influence of rotation can be divided into 2 types, one is the influence during the attachment process, the other is after the leaders connect.

The duration of the attachment process is about $8 \mu$ s from the results of high speed camera. The distance the blade moves in such short time is about $0.30 \mathrm{~mm}(200 \mathrm{r} / \mathrm{min}) /$ $0.53 \mathrm{~mm}(350 \mathrm{r} / \mathrm{min})$. For the real blade, the duration of the attachment process is about $120.4-173.9 \mu \mathrm{s}$ [15]-[17], the movement of the blade is about $4.82-17.39 \mathrm{~mm}$. so the blade can be regarded as being static during the attachment process. As a result, the attachment manner has no difference for negative condition. However, there are some cases that receptor fails to intercept the discharge for positive condition when blade is in rotation.

On the contrary, the arc-shape channel is obvious for negative discharges but not for positive discharges. The reason may be that the location of the striking attachment points of negative and positive discharges is different. Many 
of positive discharges hit on the \#2 and \#3 receptor whose linear speed are smaller the that of $\# 1$ receptor.

\section{CONCLUSION}

There are two kinds of influence due to the rotation of the blade. One is the influence on the location of the striking attachment point which is decided during the attachment process. The other is the influence on the discharge channel after the upward and downward leaders connect.

The degree of the influence depends on the polarity of the discharges. For negative discharges, the striking attachment points are not influenced by rotation, but the arc-shape channel can be observed due to the rotation. For positive discharges, the striking attachment points are dramatically influenced by rotation and the orientation of the blade, but the rotation doesn't affect the discharge channel.

There is a dramatic polarity effect for negative and positive discharges for both static and rotation condition. Much more interception failures happen to positive discharges. The protection of positive lightning strikes should be paid more attention to.

\section{REFERENCES}

[1] A. C. Garolera, "Lightning Protection of flap system for wind turbine blades," PhD thesis, Technical University of Denmark, 2014.

[2] S. Yokoyama, "Lightning protection of wind turbine blades," Electric Power Systems Research, 2013(94): 3-9.

[3] M. Abd-Elhady Amr, A. Sabiha Nehmdoh, A. Izzularab Mohamed, "Experimental evaluation of air-termination systems for wind turbine blades," Electric Power Systems Research, 2014(107), pp. 133-143.

[4] Z. Guo, Q. Li, Y. Ma, W. H. Siew, C. Chen and X. Jiang, "The performance of lightning protection system of wind turbine blade - a preliminary experimental study," in the 10th Asia-Pacific International Conference on Lightning (APL-2017), Krabi, Thailand, 2017, pp. 547-552.

[5] N. J. Vasa, T. Naka, S. Yokoyama, A. Wada, A. Asakawa, and S. Arinaga, "Experimental study on lightning attachment manner considering various types of lightning protection measures on wind turbine blades," in Proc. of the 28th International Conference on Lightning Protection (ICLP-2006), Kanazawa, Japan, 2006, pp. 14831487.
[6] S. Arinaga, K. Tsutsumi, N. Murata, T. Matsushita, M. Shibata, K. Inoue, Y. Korematsu, Y. Ueda, Y. Suguro and S. Yokoyama, "Experimental study on lightning protection methods for wind turbine blades," in Proc. of the 28th International Conference on Lightning Protection (ICLP-2006), Kanazawa, Japan, 2006, pp. 1493-1496.

[7] A. Muto, J. Suzuki, T. Ueda, "Performance comparison of wind turbine blade receptor for lightning protection," in the 30th International Conference on Lightning Protection (ICLP-2010), Cagliari, Italy, 2010, pp. 1263-1 - 1263-6.

[8] N. Wilson, J. Myers, K. Cummins, M. Hutchinson, and A. Nag, "Lightning attachment to wind turbines in central Kansas: Video observations, correlation with the NLDN and in-situ peak current measurements," EQEA, The European Wind Energy Association, Vienna, Austria, PO, 2013, 145.

[9] J. Montanyà, O. Velde, E. R. Williams, "Lightning discharges produced by wind turbines," Journal of Geophysical Research: Atmospheres, 2014, 119(3), pp. 1455-1462.

[10] M. Ishii, M. Saito, D. Natsuno, and A. Sugita, "Lightning incidence on wind turbines in winter," in Proc. of the 32nd International Conference on Lightning Protection (ICLP-2014), Shanghai, China, 2014, pp. 1734-1738.

[11] B.M. Radičević, M. S. Savić, S. F. Madsen, and I. Badea, "Impact of wind turbine blade rotation on the lightning strike incidence-A theoretical and experimental study using a reduced-size model," Energy, 2012, 45(1), pp. 644-654.

[12] IEC 61400-24: 2010 Wind turbine generator systems - Part 24: Lightning protection, IEC, 2010.

[13] J. Yan, Q. Li, Z. Guo, Y. Ma, G. Wang, L. Zhang and J. D. Yan, "Puncture position on wind turbine blades and arc path evolution under lightning strikes," Materials \& Design, 122 (2017), pp. 197205.

[14] Y. Yoh, Y. Shigeru, I. Masaru, "Verification of lightning damage classification to wind turbine blades," in the 31 st International Conference on Lightning Protection (ICLP-2012), Vienna, Austria, 2012, pp. 1-6.

[15] W. Lu, L. Chen, Y. Ma, V. A. Rakov, Y. Gao, Y. Zhang, Q. Yin and Y. Zhang, "Lightning attachment process involving connection of the downward negative leader to the lateral surface of the upward connecting leader," Geophysical Research Letters, 2013, 40(20), pp. 5531-5535.

[16] W. Shi and Q. Li, "Research on the Lightning Upward Leader Inception Based on Leader Discharge Theory," Proceedings of the CSEE, 2014, (15), pp. 2470-2477 (in Chinese).

[17] IEEE Working Group on Estimating the Lightning Performance of Overhead Transmission Lines. IEEE Guide for Improving the Lightning Performance of Transmission Lines. The Institute of Electrical and Electronics Engineers Inc, New York,1997. 